\title{
Balance Scorecard Analysis of Increasing MSME Income During the Covid 19 Pandemic in Samosir District
}

\author{
Nashrudin Setiawan ${ }^{1}$, Emi Wakhyuni $^{2}$, Abdi Setiawan $^{3}$ \\ ${ }^{123}$ Universitas Pembangunan Panca Budi \\ Correspondent: nashrudinsetiawan@dosen.pancabudi.ac.id
}

Received : August 08, 2021

Accepted : August 25, 2021

Published : October 31, 2021

Citation: Setiawan, N., Wakhyuni, E., Setiawan, A. (2021). Balance Scorecard Analysis of Increasing MSME Income During the Covid 19 Pandemic in Samosir District. Ilomata International Journal of Social Science, 2(4), 233-245. https://doi.org/10.52728/ijss.v2i4.357
ABSTRACT: Micro, Small and Medium Enterprises (MSMEs) are the lifeblood of the regional and national economy. In general, MSMEs in the national economy have the following roles: (1) as the main actors in economic activities, (2) the largest provider of employment, (3) important players in local economic development and community empowerment, (4) creating new markets and sources of innovation, and (5) its contribution to the balance of payments. In addition, MSMEs also have an important role, especially in the perspective of employment opportunities and sources of income for the poor, income distribution and poverty reduction, and MSMEs also play a role in rural economic development. The existence of the 2019 Coronavirus disease (Covid 19 pandemic) at the end of 2019 became an international problem, including in Indonesia. The COVID-19 pandemic has had economic, social, and and politics in almost all countries, including Indonesia. The economic impact of the COVID-19 pandemic has also been felt by the MSME sector in Samosir Regency. The impact caused by this pandemic includes 5 aspects, namely 1) Sales aspects. The average decline in MSME sales is $61 \%, 2$ ) Aspects of operating profit. The average decrease in operating profit is $62 \%, 3)$ Capital aspect. The number of MSMEs experiencing capital problems increased to $71.4 \%$, 4) Aspects of the number of employees. In this aspect, MSMEs reduced the number of employees by $22 \%$, and 5) Aspects of the ability to pay bank installments. Almost all MSME actors (especially microenterprises) experience problems in carrying out their obligations to banks. This study also found that MSME actors in Samosir Regency had implemented an online sales strategy, although not all. The number of MSMEs that carry out online strategies has increased during the Covid 19. The survival ability of MSMEs that sell online is stronger than MSMEs that only sell offline.

Keywords: Micro Small And Medium Enterprises, Balance Score Card, Performance Appraisal 


\section{Balance Scorecard Analysis of Increasing MSME Income During the Covid 19 Pandemic in Samosir District \\ Setiawan, N., Wakhyuni., Setiawan, A}

\section{INTRODUCTION}

Micro, Small and Medium Enterprises (MSMEs) as an organization are required to have good performance. Performance is a world issue today. This happens as a consequence of the community's demands for the need for excellent service or high quality services. Quality is inseparable from standards, because performance is measured by standards. Through performance, it is expected to show real professional contributions in improving the quality of services which have an impact on services in general for MSMEs, and the final impact leads to the quality of life and welfare of the community. The existence of the COVID-19 pandemic that occurred in Indonesia and almost all countries in the world, greatly affected all industrial sectors, including MSMEs, therefore MSME actors need to work hard, work smart through change and innovation of its business and services in order to continue to achieve good performance. In order for the performance of MSMEs to be good, a measuring tool is needed to determine the extent to which the performance success rate of MSMEs themselves (Nordhagen et al., 2021; Shafi et al., 2020).

One of the tools to measure performance is to use the Balanced Scorecard. The Balanced Scorecard is a strategic tool for measuring company performance that is integrated in 4 perspectives, namely financial, customer, internal processes and learning and growth perspectives. Balanced scorecard is a management system mechanism that is able to translate the vision and strategy of the organization into real action in the field. The Balanced Scorecard is a proven management tool that has helped many companies implement their business strategies. The Balanced Scorecard is expected to produce strategic decisions to improve MSME performance. The balance scorecard will measure in 4 perspectives, namely the financial perspective, namely the increase in revenue and cost efficiency. In the customer perspective, it will be measured about increasing the number of customers and reducing the number of customer complaints. In the internal perspective, the process will be analyzed regarding increasing service processing time and after-sales service efficiency. In the learning and growth perspective, it will be analyzed about improving employee skills and maintaining employee retention. The regional economy is generally supported by micro, small and medium scale economic activities. Business units that fall into the category of micro-enterprises, Small and medium enterprises (MSMEs) are the lifeblood of the regional and national economy (Kartalis et al., 2013; Senarath \& Patabendige, 2015).

MSMEs are the main players in economic activity in Indonesia. In general, MSMEs in the national economy have the following roles: (1) as the main actors in economic activities, (2) the largest provider of employment, (3) important players in local economic development and community empowerment, (4) creating new markets and sources of innovation, and (5) its contribution to the balance of payments. In addition, MSMEs also have an important role, especially in the perspective of employment opportunities and sources of income for the poor, income distribution and poverty reduction, and MSMEs also play a role in rural economic development. In general, MSMEs in the national economy have the following roles: (1) as the main actors in economic activities, (2) the largest provider of employment, (3) important players in local economic development and community empowerment, (4) creating new markets and sources of innovation, and (5) its contribution to the balance of payments. In addition, MSMEs also have an important role, especially in the perspective of employment opportunities and 


\section{Balance Scorecard Analysis of Increasing MSME Income During the Covid 19 Pandemic in Samosir District \\ Setiawan, N., Wakhyuni., Setiawan, A}

sources of income for the poor, income distribution and poverty reduction, and MSMEs also play a role in rural economic development. (Bai et al., 2021; Dewi \& Mahendrawathi, 2019)

In general, MSMEs in the national economy have the following roles: (1) as the main actors in economic activities, (2) the largest provider of employment, (3) important players in local economic development and community empowerment, (4) creating new markets and sources of innovation, and (5) its contribution to the balance of payments. In addition, MSMEs also have an important role, especially in the perspective of employment opportunities and sources of income for the poor, income distribution and poverty reduction, and MSMEs also play a role in rural economic development (Syuhada \& Gambetta, 2013; Trinh et al., 2020).

North Sumatra Province is one area that has an important role in growing tourism and small businesses such as MSMEs. The contribution of the MSME sector to the economic growth of North Sumatra Province is very large. MSMEs are able to absorb a large number of workers. Therefore, the existence of MSMEs should continue to be empowered. Thus, it is hoped that MSMEs can develop for the better and spur the growth of other businesses so that they can improve the welfare of the community.

The main problems in this research are to answer the questions; (1) What is the impact of the Covid 19 pandemic on MSMEs in Samosir Regency; and (2) What are the strategic steps that must be taken by MSMEs and the Government to maintain their existence in the post-Covid-19 pandemic. The purpose of this research activity is to find out and determine the impact of the Covid 19 pandemic on MSMEs in Samosir Regency and the strategic steps that must be taken by MSMEs and the government to maintain their existence in the post-Covid-19 pandemic. The target/target to be achieved in this research is solving the problems faced by MSMEs during the Covid 19 pandemic through efforts and or policies from the government. This research was carried out by the Regional Research, Development and Innovation Agency with the scope of research within the Government of Samosir Regency and specializing the research location at the Department of Trade, Industry, Cooperatives and SMEs of Samosir Regency. The beneficiaries of this research are all MSME actors in Samosir Regency, Samosir Regency Regional Government, other economic actors and the wider community who need information related to this research.

\section{METHOD}

Micro, Small and Medium Enterprises (MSMEs) as an organization are required to have good performance. Performance is a world issue today. This happens as a consequence of the community's demands for the need for excellent service or high quality services. Quality is inseparable from standards, because performance is measured by standards. Through performance, it is expected to show real professional contributions in improving the quality of services which have an impact on services in general for MSMEs, and the final impact leads to the quality of life and welfare of the community. The existence of the COVID-19 pandemic that occurred in Indonesia and almost all countries in the world, greatly affected all industrial sectors, including MSMEs, therefore MSME actors need to work hard, work smart through change and innovation of its business and services in order to continue to achieve good performance. In order for the performance of MSMEs to be good, a measuring tool is needed to determine the 


\section{Balance Scorecard Analysis of Increasing MSME Income During the Covid 19 Pandemic in Samosir District \\ Setiawan, N., Wakhyuni., Setiawan, A}

extent to which the performance success rate of MSMEs themselves (Nordhagen et al., 2021; Shafi et al., 2020).

One of the tools to measure performance is to use the Balanced Scorecard. The Balanced Scorecard is a strategic tool for measuring company performance that is integrated in 4 perspectives, namely financial, customer, internal processes and learning and growth perspectives. Balanced scorecard is a management system mechanism that is able to translate the vision and strategy of the organization into real action in the field. The Balanced Scorecard is a proven management tool that has helped many companies implement their business strategies. The Balanced Scorecard is expected to produce strategic decisions to improve MSME performance. The balance scorecard will measure in 4 perspectives, namely the financial perspective, namely the increase in revenue and cost efficiency. In the customer perspective, it will be measured about increasing the number of customers and reducing the number of customer complaints. In the internal perspective, the process will be analyzed regarding increasing service processing time and after-sales service efficiency. In the learning and growth perspective, it will be analyzed about improving employee skills and maintaining employee retention. The regional economy is generally supported by micro, small and medium scale economic activities. Business units that fall into the category of micro-enterprises, Small and medium enterprises (MSMEs) are the lifeblood of the regional and national economy (Kartalis et al., 2013; Senarath \& Patabendige, 2015).

MSMEs are the main players in economic activity in Indonesia. In general, MSMEs in the national economy have the following roles: (1) as the main actors in economic activities, (2) the largest provider of employment, (3) important players in local economic development and community empowerment, (4) creating new markets and sources of innovation, and (5) its contribution to the balance of payments. In addition, MSMEs also have an important role, especially in the perspective of employment opportunities and sources of income for the poor, income distribution and poverty reduction, and MSMEs also play a role in rural economic development. In general, MSMEs in the national economy have the following roles: (1) as the main actors in economic activities, (2) the largest provider of employment, (3) important players in local economic development and community empowerment, (4) creating new markets and sources of innovation, and (5) its contribution to the balance of payments. In addition, MSMEs also have an important role, especially in the perspective of employment opportunities and sources of income for the poor, income distribution and poverty reduction, and MSMEs also play a role in rural economic development. (Bai et al., 2021; Dewi \& Mahendrawathi, 2019)

In general, MSMEs in the national economy have the following roles: (1) as the main actors in economic activities, (2) the largest provider of employment, (3) important players in local economic development and community empowerment, (4) creating new markets and sources of innovation, and (5) its contribution to the balance of payments. In addition, MSMEs also have an important role, especially in the perspective of employment opportunities and sources of income for the poor, income distribution and poverty reduction, and MSMEs also play a role in rural economic development (Syuhada \& Gambetta, 2013; Trinh et al., 2020).

North Sumatra Province is one area that has an important role in growing tourism and small businesses such as MSMEs. The contribution of the MSME sector to the economic growth of North Sumatra Province is very large. MSMEs are able to absorb a large number of workers. Therefore, the existence of MSMEs should continue to be empowered. Thus, it is hoped that 


\section{Balance Scorecard Analysis of Increasing MSME Income During the Covid 19 Pandemic in Samosir District \\ Setiawan, N., Wakhyuni., Setiawan, A}

MSMEs can develop for the better and spur the growth of other businesses so that they can improve the welfare of the community.

The main problems in this research are to answer the questions; (1) What is the impact of the Covid 19 pandemic on MSMEs in Samosir Regency; and (2) What are the strategic steps that must be taken by MSMEs and the Government to maintain their existence in the post-Covid-19 pandemic. The purpose of this research activity is to find out and determine the impact of the Covid 19 pandemic on MSMEs in Samosir Regency and the strategic steps that must be taken by MSMEs and the government to maintain their existence in the post-Covid-19 pandemic. The target/target to be achieved in this research is solving the problems faced by MSMEs during the Covid 19 pandemic through efforts and or policies from the government. This research was carried out by the Regional Research, Development and Innovation Agency with the scope of research within the Government of Samosir Regency and specializing the research location at the Department of Trade, Industry, Cooperatives and SMEs of Samosir Regency. The beneficiaries of this research are all MSME actors in Samosir Regency, Samosir Regency Regional Government, other economic actors and the wider community who need information related to this research.

\section{RESULT AND DISCUSSION}

Based on the results of questionnaires and interviews conducted with MSME actors in Samosir Regency, it was found that in general MSME actors were affected either directly or indirectly. A total of $45.71 \%$ of MSMEs did not experience problems due to Covid-19. The MSMEs that do not experience these problems are MSMEs engaged in health, food and food processing. This shows that during the Covid-19 era, people still need food to increase their immune system and health equipment. Even during the Covid-19 pandemic, the food industry was the most sought after item by the public for work from home. Likewise with medical equipment, had experienced a surge in demand and price spikes. This is due to rumors that some medical equipment such as masks, hand sanitizer, alcohol and others will be scarce in the market. As a result, people buy up medical devices on the market, which results in a shortage of goods and an increase in prices. This condition did not last long, because the government was able to control the market and make policies that were pro to the provision of medical equipment for the community, and even gave free donations.

However, it turns out that the negative impact of Covid-19 on MSMEs is $54.29 \%$. This is due to several policies related to: (1)restrictions on opening shops, stalls, kiosks and markets, (2) work from home policies and a shift system between employees, and (3) restrictions on crowds or crowds. The policy of limiting the opening of shops, stalls, kiosks and markets has caused a sluggish economy and people are reluctant to shop. The community will only buy basic necessities, while those that are considered economically productive will still be empowered. Likewise, MSMEs sell on a limited basis in markets, stalls, kiosks and private housing. On the other hand, the work from home policy for office employees makes the demand process decrease. Since almost all office workers work from home, they have time to cook for their families and are reluctant to go out to buy food. Even some products that previously had to be purchased are now made at home, so they can fill their spare time. Moreover, the policy of prohibiting crowds has made tourist places deserted, even closed. Saturdays and Sundays which 


\section{Balance Scorecard Analysis of Increasing MSME Income During the Covid 19 Pandemic in Samosir District \\ Setiawan, N., Wakhyuni., Setiawan, A}

are usually used for holidays and buying various food, drinks and toys with crowd restrictions no longer occur (DesJardine et al., 2019).

The impact of the Covid 19 pandemic on MSMEs in Samosir Regency, namely problems in the distribution process of raw materials, decreased profits, decreased sales, reduced number of employees and capital. First, the slow distribution of raw materials causes some scarcity of raw materials used to make MSME products. In the first month of Covid 19, large-scale restrictions applied in several regions and the existence of licensing rules for passing through ports by submitting a Covid 19 free letter caused distribution not to go well. In fact, some of the products that were previously able to enter and leave in Samosir Regency are in scarcity. This is also due to the panic effect of consumers by buying up certain products, resulting in scarcity in the market. At the beginning of the Covid-19 pandemic, most people were afraid to go out and did not dare to meet other people, for fear of being exposed to Covid-19 which was considered deadly. For almost three months, the streets have become deserted with vehicles passing by, including vehicles transporting raw materials for various MSME products. However, this condition did not last long, because at this time the distribution of goods was running normally (Eggers, 2020).

The public has received good education from the government by implementing health protocols, namely by always wearing masks, washing hands with soap and keeping a distance. Finally, people with looser policies than the government carry out activities, although they are still limited. for fear of being exposed to Covid-19 which is considered deadly. For almost three months, the streets have become deserted with vehicles passing by, including vehicles transporting raw materials for various MSME products. However, this condition did not last long, because at this time the distribution of goods was running normally. The public has received good education from the government by implementing health protocols, namely by always wearing masks, washing hands with soap and keeping a distance. Finally, people with looser policies than the government carry out activities, although they are still limited. for fear of being exposed to Covid-19 which is considered deadly. For almost three months, the streets have become deserted with vehicles passing by, including vehicles transporting raw materials for various MSME products. However, this condition did not last long, because at this time the distribution of goods was running normally. The public has received good education from the government by implementing health protocols, namely by always wearing masks, washing hands with soap and keeping a distance. Finally, people with looser policies than the government carry out activities, although they are still limited. However, this condition did not last long, because at this time the distribution of goods was running normally. The public has received good education from the government by implementing health protocols, namely by always wearing masks, washing hands with soap and keeping a distance. Finally, people with looser policies than the government carry out activities, although they are still limited. However, this condition did not last long, because at this time the distribution of goods was running normally. The public has received good education from the government by implementing health protocols, namely by always wearing masks, washing hands with soap and keeping a distance. Finally, people with looser policies than the government carry out activities, although they are still limited.

Schematically, the impact of the Covid-19 pandemic on MSME productivity in Samosir Regency can be described as follows: 


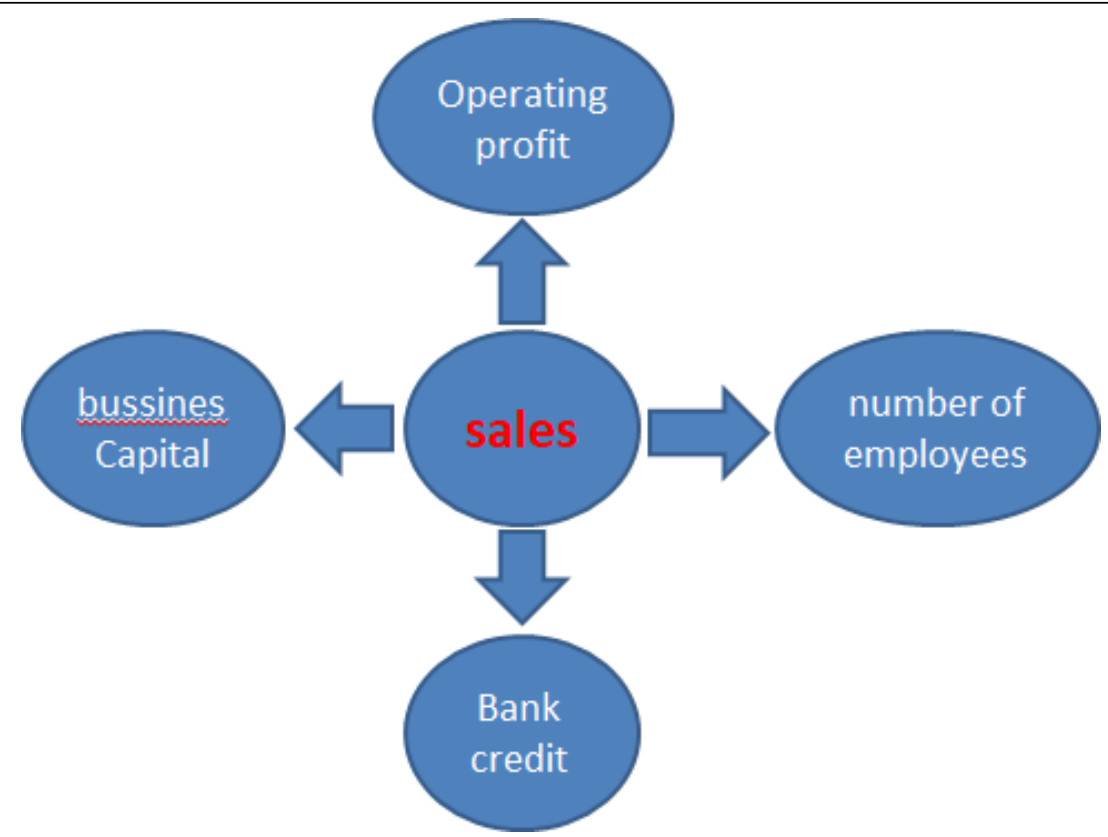

Figure 1. Impact of Covid on MSME Productivity

Second, a decrease in profit. Profit is the increase in an investor's wealth as a result of investingcapital after deducting the costs associated with the investment. Profit can also be interpreted as the difference between the selling price and the cost of production. Profit or net income is operating profit minus taxes, interest costs, research and development costs. Net income is presented in the income statement by juxtaposing revenues with expenses. Profit can be divided into two, namely a pure economic understanding and an accounting understanding. Profit in economics can be interpreted as the profit earned by an investor in a business activity. This of course has been reduced by the operational costs that exist in a business that is run. This will make it easier to understand profit or what is generally known as profit. Meanwhile, profit according to accounting science is defined as the difference between the selling price and the costs incurred at the time of production.

The elements of profit can be divided into: (1) income, which is a result of what someone does This income can be understood as a salary or something that is earned after working or after doing a business, (2) expenses, which are things that must be issued or what someone must be responsible for to get an expected result. The burden will be very important to fulfill so that you will get the profit or profit you are looking for, (3) the cost is something that must be sacrificed in a business or venture. In this case, costs can be interpreted as things that must be cash in a business. Costs are used as a means of driving the business so that it continues to run well and provide benefits that are in line with expectations, (4) the advantages and disadvantages are understood by many people even by people who are not in the economic world. In this case, Profit is one of the things that will be obtained by someone who does business. This will make people earn their income. In addition, loss is something that all business owners avoid, and (5) income, which is the end result of the business. This income can be used for life. There is nothing that cannot be done to provide a high income. All kinds of ways can be done so that a business can earn high profits. There is nothing that cannot be done to provide a high income. All kinds of ways can be done so that a business can earn high profits. There is nothing that cannot be done to provide a high income. All kinds of ways can be done so that a business can earn high profits. 


\section{Balance Scorecard Analysis of Increasing MSME Income During the Covid 19 Pandemic in Samosir District \\ Setiawan, N., Wakhyuni., Setiawan, A}

The decline in product sales concerns the quantity, type of product and the number of MSME profits in Samosir Regency. Quantity is the number of products sold every day and every month has decreased. Likewise, the types of products that are sold every day and every month show a downward trend since the Covid 19 pandemic occurred. This condition has implications for the decline in MSME profits or income which has decreased significantly. Statistical analysis shows the average decline in MSME profits in Samosir Regency is 61\%.

Third, a decline in sales. Based on data analysis, it can be seen that the decline in sales of MSMEs in Samosir Regency is 61\%. Sales activity is very important for the company, especially for profit. Sales is one of the marketing functions that determine the company in achieving the company's goals, namely to earn profits to maintain the survival of the company. Sales are the lifeblood of a company, because from sales profit can be obtained as well as an effort to attract consumers who are endeavored to find out the attractiveness of consumers so that they can know the results of the products produced. Sales is an activity or business in selling products or services. Understanding sales in general is buying and selling activities carried out by two or more parties with legal tender. Sales is an activity aimed at finding buyers, influencing and providing instructions so that buyers can adjust their needs to the products offered and enter into agreements regarding prices that are profitable for both parties. This sale can be done by various methods, such as direct sales and sales agents. The main purpose of selling is to make a profit from the product or goods being sold. In practice, sales cannot be made without contributions from working actors, such as traders, agents, and marketing personnel. Influence and provide instructions so that buyers can adjust their needs with the products offered and enter into agreements regarding prices that are beneficial for both parties. This sale can be done by various methods, such as direct sales and sales agents. The main purpose of selling is to make a profit from the product or goods being sold. In practice, sales cannot be made without contributions from working actors, such as traders, agents, and marketing personnel.

The following figure explains the impact of a decrease in sales which will also have an impact on a decrease in operating profit and a decrease in the number of employees:

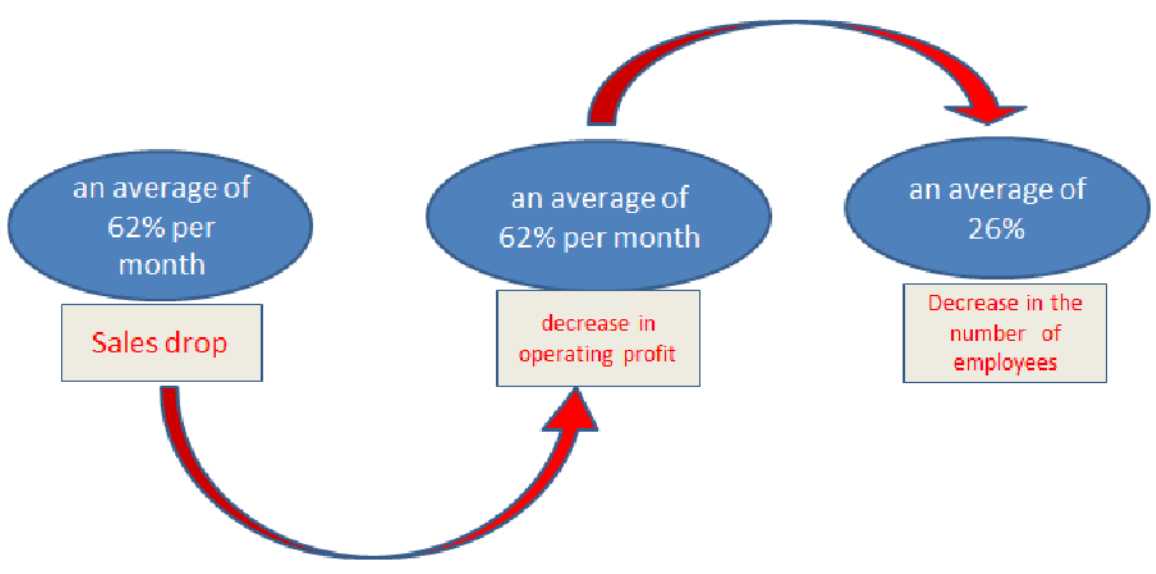

Figure 2. The Impact of Covid on MSME Sales

Fourth, lead to a reduction in the number of employees. Every company needs employees as workers who carry out every activity in the company's organization. Employees are the most important asset that has a huge influence on the success of a company. Without sophisticated 


\section{Balance Scorecard Analysis of Increasing MSME Income During the Covid 19 Pandemic in Samosir District \\ Setiawan, N., Wakhyuni., Setiawan, A}

machines, companies can continue to operate manually, but without employees, companies will not be able to run at all. Employees are those who work in a company or institution to carry out operational tasks and expect remuneration in the form of commissions (money). According to Law number 13 of 2003 concerning employment, article 1 paragraph 2 states that an employee is anyone who is able to do work to produce goods and services both to meet their own needs and that of the community. both inside and outside the work relationship. From this definition, what is meant by workers who do work in an employment relationship are workers who do work in any form of business (company) or individuals by receiving wages including workers who do work outside the employment relationship.

The roles and responsibilities of employees to the company, namely: (1) comply with the regulations that have been set. Each company usually has its own rules for all employees to obey (2) maintain job stability. Maintaining job stability is a challenge, the decline and increase in work productivity is a phase that definitely exists and will continue to occur. For the sake of business continuity in a company, employees must face various challenges to maintain work stability such as not extending rest periods and using rest periods wisely, (3) respecting everyone. An employee must not only respect his superiors, employees must also respect his co-workers and clients. (4) maintain and establish good communication. Employees must be good at maintaining and establishing communication between him and his superiors, coworkers and employeesclient.(5) maintain company privacy. Employees have a very large role in a company, including in terms of maintaining company privacy such as data or informationprivacydetermined by the company, (6) maintain the good name of the company, (7) give a warning. Give warnings and take wise steps if you suspect that there is a possibility of a violation of the law, code of ethics and code of conduct contained in the company. The decrease in demand and sales causes the need for production to decrease. The implication is that there is a reduction in the number of employees working in the MSME sector after Covid 19. According to MSMEs that have more than one employee, there are two strategies taken, namely by temporarily laying off their employees and using the shift system.

Fifth, there are difficulties in making bank installment payments used by MSMEs. Capital is something that cannot be separated from business/business activities, investments, and various activities that aim to gain profit or income. For companies that have just been established or have started running their business, capital is used to be able to carry out business activities, while for companies or business fields or businesses that have been around for a long time, capital is usually used to be able to develop businesses and expand the market share of these businesses and businesses. For entrepreneurs, they should be able to use / utilize capital as optimally as possible, which is later expected to be able to provide maximum profits for the company being managed. 


\section{Balance Scorecard Analysis of Increasing MSME Income During the Covid 19 Pandemic in Samosir District \\ Setiawan, N., Wakhyuni., Setiawan, A}

\section{CONCLUSION}

The results of the FGD and interviews conducted with MSME actors, it was found that the Samosir Regency Government has been responsive to the condition of MSMEs after Covid 19. The banking sector has also issued policies to help MSMEs, as well as MSME actors themselves have made efforts to remain productive after Covid-19. The efforts that have been made by the Samosir Regency Government through the Social Service, Trade, Industry, Cooperatives and SMEs Offices as well as other district government agencies, Banking and MSME actors can be described as follows:

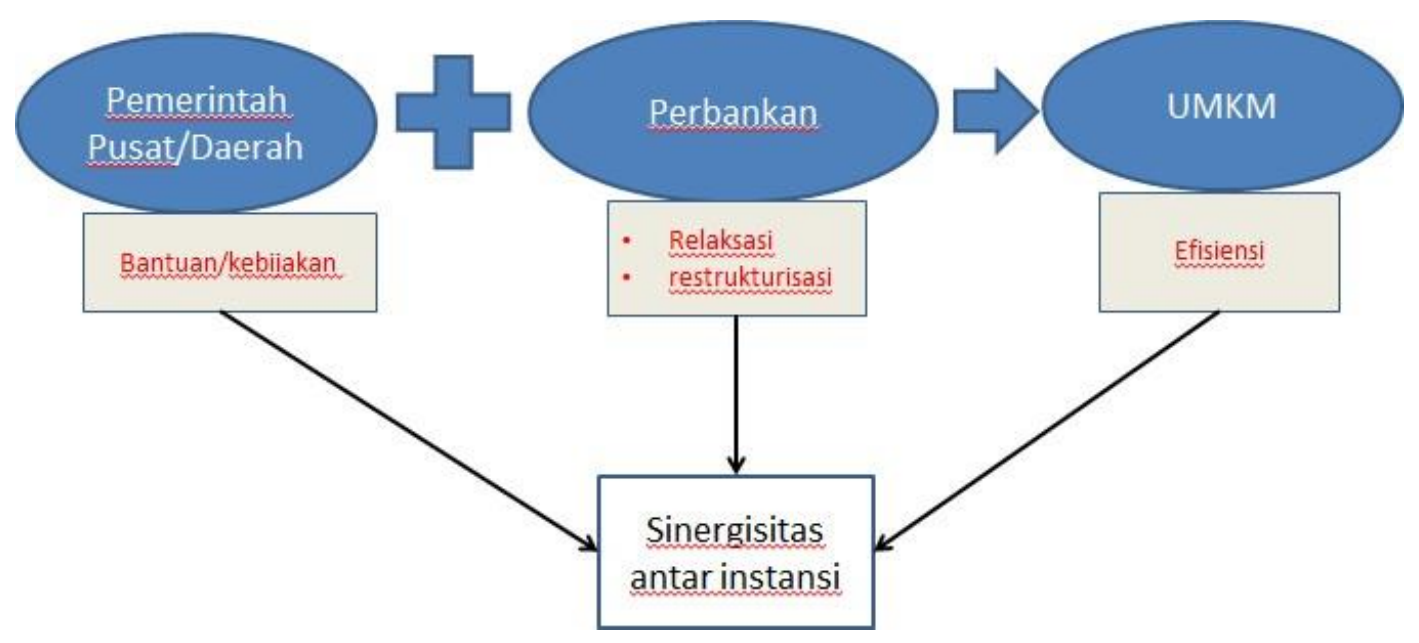

Figure 3. MSMEs Synergy

The government has carried out direct cash assistance,Bantuan Langsung Tunai (BLT) which eased the economic burden on the community in the midst of the corona virus outbreak. The number of customer databases that must be entered into the system is approximately 500 thousand customer IDs. Meanwhile, the direct cash program is assistance provided directly through the beneficiary's account. The distribution of assistance for the first phase of capital to beneficiaries has been carried out. The government has budgeted Rp22 trillion in the first phase to reach 9.1 million MSMEs.

There are a number of conditions that must be met by MSMEs in order to receive capital assistance, namely: (1) business actors are Indonesian citizens (WNI), (2) have a Population Identification Number (KTP), (3) have a micro business as evidenced by a proposal letter. from the proposer, the attachment is not ASN, TNI/Polri, or BUMN/BUMD employees. Meanwhile, the proposal is made by an authorized proposing agency, then the data is verified and validated by the Ministry of Cooperatives and SMEs together with the Ministry of Finance and OJK. Method of distribution The distribution of funds amounting to Rp. 2.4 million is given in one transfer, directly through the registered accounts of MSME actors. The government appointed Bank Rakyat Indonesia (BRI) and Bank Negara Indonesia (BNI) to distribute aid. For the first phase, BRI has distributed to 683,528 beneficiaries with a total of Rp1.64 trillion.

Meanwhile, BNI has distributed assistance to 316,472 beneficiaries, with a total of IDR 760 billion. 4 million is given in one transfer, directly through the registered account of MSME actors. The government appointed Bank Rakyat Indonesia (BRI) and Bank Negara Indonesia (BNI) to distribute aid. For the first phase, BRI has distributed to 683,528 beneficiaries with a 


\section{Balance Scorecard Analysis of Increasing MSME Income During the Covid 19 Pandemic in Samosir District \\ Setiawan, N., Wakhyuni., Setiawan, A}

total of Rp1.64 trillion. Meanwhile, BNI has distributed assistance to 316,472 beneficiaries, with a total of IDR 760 billion. 4 million is given in one transfer, directly through the registered account of MSME actors. The government appointed Bank Rakyat Indonesia (BRI) and Bank Negara Indonesia (BNI) to distribute aid. For the first phase, BRI has distributed to 683,528 beneficiaries with a total of Rp1.64 trillion. Meanwhile, BNI has distributed assistance to 316,472 beneficiaries, with a total of IDR 760 billion.

The follow-up to this central government assistance has been carried out by the Samosir Regency Government through the Samosir Regency Department of Trade, Industry and Cooperatives, Small and Medium Enterprises (Disdagprinkop UKM). A total of 11,554 Micro, Small and Medium Enterprises (MSMEs) affected by the Covid- 19 pandemic in 9 sub-districts of Samosir Regency were proposed as candidates for recipients of productive social assistance for micro businesses worth IDR 2.4 million from the Center. This application for assistance for MSMEs has been proposed by the Office of Trade, Industry and Cooperatives, Small and Medium Enterprises (Disdagprinkop UKM) of Samosir Regency. With this program, it is hoped that micro- enterprises will continue to be maintained. This assistance is intended to encourage MSME actors to continue their activities and can be used to buy production needs, operational costs, and so on.

Meanwhile, banks have launched various programs such as reduced interest rates and installments for MSMEs. As done by Bank Rakyat Indonesia, for example, by providing incentives to micro, small and retail customers by lowering the Basic Loan Interest Rate (SBDK) up to 50 basis points. This step is part of the relaxation provided by Bank Rakyat Indonesia for MSME players in difficult times. In principle, Bank Rakyat Indonesia is always responsive and ready to countercyclical in the midst of the challenges of the Covid-19 outbreak with various relaxation policies and efforts to maintain business continuity for every MSME customer. Furthermore, we continue to strive to implement prudential banking and continue to conduct healthy business expansion with selective growth. Especially for Micro, Small and Medium Enterprises (MSMEs).

The results of the study also found that between MSMEs that did online marketing and offline marketing experienced different impacts. In general, sales made online are more resilient in terms of sales and profits. However, the reduction in MSME employees who use the online sales model is higher. The data regarding MSMEs that go online and offline after Covid-19 can be presented as follows:

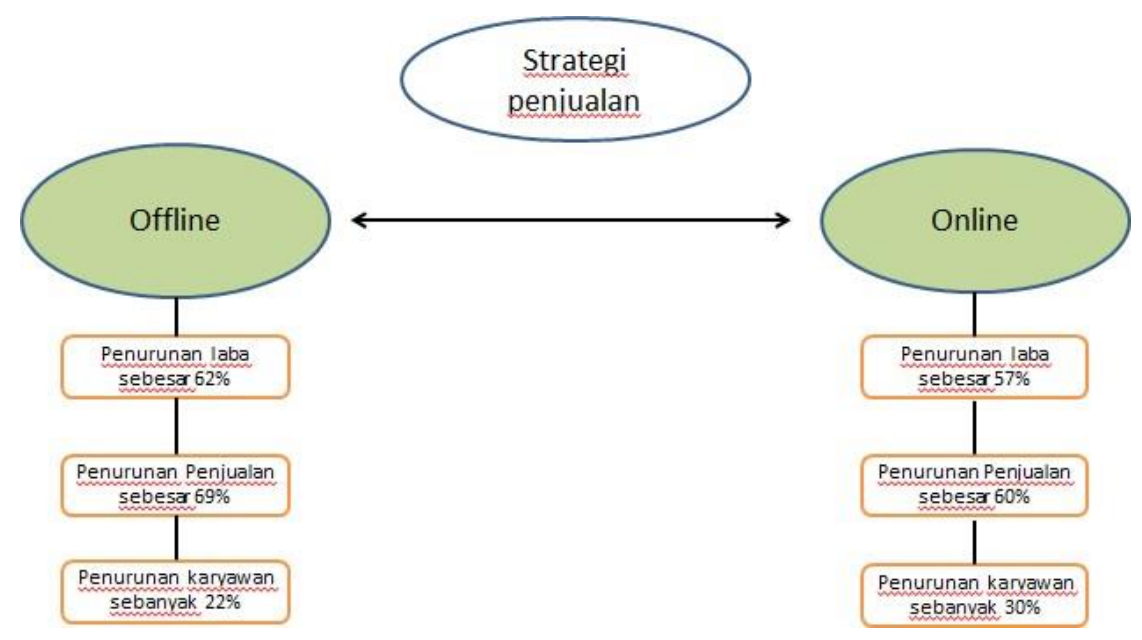

Figure 4. MSMEs Selling Strategy 


\section{Balance Scorecard Analysis of Increasing MSME Income During the Covid 19 Pandemic in Samosir District \\ Setiawan, N., Wakhyuni., Setiawan, A}

Based on the data above, it can be concluded that MSMEs that do marketing offline have decreased profits by $62 \%$, while MSMEs that do marketing online have decreased profits by $57 \%$. This means that MSMEs that have used online marketing are more resilient than offline in the profit sector with a difference of $5 \%$. The data above also shows that MSMEs that do marketing offline have decreased sales by $69 \%$, while MSMEs that do marketing online have decreased profits by $60 \%$. This means that MSMEs that use online marketing are more resistant than offline in sales with a difference of $9 \%$.

Meanwhile, related to the decrease in employees, MSMEs that did offline marketing experienced a decrease in employees by $22 \%$, while MSMEs that do online marketing have decreased employees by $30 \%$. This means that MSMEs that use online marketing have a greater reduction in employees compared to offline with a difference of $8 \%$. To strengthen the marketing of digital-based MSME products, the Samosir Regency Government has developed and launched "Digital Marketing for the Samosir e-Onan Application", which was inaugurated in the Samosir Regent's Office Hall, on Friday, 13/8/2021. The application of this Digital Marketing Application is one of the priority program agendas for the Regent/Vice Regent of Samosir for 100 working days. To strengthen the marketing of digital-based MSME products, the Samosir Regency Government has developed and launched "Digital Marketing for the Samosir e-Onan Application", which was inaugurated in the Samosir Regent's Office Hall, on Friday, 13/8/2021. The application of this Digital Marketing Application is one of the priority program agendas for the Regent/Vice Regent of Samosir for 100 working days. To strengthen the marketing of digital-based MSME products, the Samosir Regency Government has developed and launched "Digital Marketing for the Samosir e-Onan Application", which was inaugurated in the Samosir Regent's Office Hall, on Friday, 13/8/2021. The application of this Digital Marketing Application is one of the priority program agendas for the Regent/Vice Regent of Samosir for 100 working days.

The launching of the Samosir e-Onan application is also a step in providing information as well as introducing local products from Samosir Regency. The implementation of digital marketing in the form of this application is also a form of facilitation for the Samosir Regency Government in providing a market place for MSME actors to carry out promotions and buying and selling activities which during the Covid- 19 pandemic there has been a change in marketing business strategy from conventional patterns to online businesses. . It is hoped that with these various strategies and breakthroughs, the performance of MSME actors can grow.

\section{REFERENCE}

Bai, C., Quayson, M., \& Sarkis, J. (2021). COVID-19 pandemic digitization lessons for sustainable development of micro-and small- enterprises. Sustainable Production and Consumption, 27, 1989-2001. https://doi.org/10.1016/j.spc.2021.04.035

DesJardine, M., Bansal, P., \& Yang, Y. (2019). Bouncing Back: Building Resilience Through Social and Environmental Practices in the Context of the 2008 Global Financial Crisis. Journal of Management, 45(4), 1434-1460. https://doi.org/10.1177/0149206317708854

Dewi, F., \& Mahendrawathi. (2019). Business Process Maturity Level of MSMEs in East Java, Indonesia. Procedia Computer Science, 161, 1098-1105. https://doi.org/10.1016/j.procs.2019.11.221

Eggers, F. (2020). Masters of disasters? Challenges and opportunities for SMEs in times of crisis. 
Balance Scorecard Analysis of Increasing MSME Income During the Covid 19 Pandemic in Samosir District

Setiawan, N., Wakhyuni., Setiawan, A

Journal of Business Research, 116, 199-208. https://doi.org/10.1016/j.jbusres.2020.05.025

Kartalis, N., Velentzas, J., \& Broni, G. (2013). Balance Scorecard and Performance Measurement in a Greek Industry. Procedia Economics and Finance, 5, 413-422. https://doi.org/10.1016/S2212-5671(13)00049-X

Nordhagen, S., Igbeka, U., Rowlands, H., Shine, R. S., Heneghan, E., \& Tench, J. (2021). COVID-19 and small enterprises in the food supply chain: Early impacts and implications for longer-term food system resilience in low- and middle-income countries. World Development, 141, 105405. https://doi.org/10.1016/j.worlddev.2021.105405

Senarath, S. A. C. L., \& Patabendige, S. S. J. (2015). Balance Scorecard: Translating Corporate Plan into Action. A Case Study on University of Kelaniya, Sri Lanka. Procedia - Social and Behavioral Sciences, 172, 278-285. https://doi.org/10.1016/j.sbspro.2015.01.365

Shafi, M., Liu, J., \& Ren, W. (2020). Impact of COVID-19 pandemic on micro, small, and medium-sized Enterprises operating in Pakistan. Research in Globalization, 2, 100018. https://doi.org/10.1016/j.resglo.2020.100018

Sugiyono. (2017). Metode Penelitian Kuantitatif Kualitatif dan R\&D. Alfabeta.

Syuhada, A., \& Gambetta, W. (2013). Online Marketplace for Indonesian Micro Small and Medium Enterprises Based on Social Media. The 4th International Conference on Electrical Engineering and Informatics (ICEEI 2013), 446-454. https://doi.org/https://www.sciencedirect.com/science/article/pii/S221201731300368X

Trinh, Q. L., Morgan, P. J., \& Sonobe, T. (2020). Investment behavior of MSMEs during the downturn periods: Empirical evidence from Vietnam. Emerging Markets Review, 45, 100739. https://doi.org/10.1016/j.ememar.2020.100739 